\title{
土木学会高炉スラグ砕石コンクリート設計施工指針 (案)
}

小 林 正 几*

高炉スラグは製鉄の際の副産物であり，高炉セメント の製造原料として古くから利用されてきたが，最近では 骨材資源の枯渇問題等が深刻化してきたため, これをコ ンクリート用骨材として活用することに深い関心が寄せ られている。高炉スラグを骨材として利用する場合には， 高炉スラグ砕石, 水砕スラグ砂, 膨張スラグ骨材等各種 の方法があげられるが, 水砕スラグ砂については一部で 実用化の試みが進められているもののなお検討すべき問 題が残されており，また膨張スラグ骨材についても，ま だ研究の段階にある。高炉スラグをコンクリート用粗骨 材として使用することについての研究は当初, アメリ カ, 西ドイッ, イギリス, フランス等において積極的に 進められ, 1879 年にはイギリスでマスコンクリートに, 1887 年にはアメリカで鉄筋コンクリートに, また 1912 年には同じくアメリカで舗装コンクリートに使用された 実績があり, 最近ではプレストレストコンクリートに使 われた例もある。わが国でも 1927 年に工場建物の工事 に使用された例があり, 使用の歴史は 50 年以上にも及 んでいる。しかし，ごく最近までは我が国では，使用の 範囲が主として製鉄所構内の工事に限られ，一般にはほ とんど顧みられない状態にあったといえる。

土木学会コンクリート委員会では, 高炉スラグ砕石が JIS A 5011 「ンクリート用高炉スラグ粗骨材」として 品質規格の制定がなされたのを機会に, 高炉スラグ小委 員会（委員長国分正胤教授）を設け，高炉スラグ砕石を 一般の鉄筋コンクリート工事に用いる場合を対象として 設計施工の標準について審議し，表題のような指針(案) を作成した。以下にその概要を示す。

1. 総則この指針は高炉スラグ砕石を通常の土木 構造物の無筋及び鉄筋コンクリートに使用する場合を対 象として定めたものであることが示されている。この種 の砕石に関する使用実績は, 上述の諸外国では広範囲に わたっているが, わが国では研究が本格化したのが最近 のことであるため,一般の工事に使用された例は少ない, そこで特に重要な鉄筋コンクリートあるいはプレストレ ストコンクリートの構造物の工事に使用寸る場合には, あらかじめ綿密な調査と試験を行うようすすめている。

2. 高炉スラグ砕石 現在我が国で生産されている 高炉スラグ砕石は,化学成分についての差異は少ないが,

* 正会員 法政大学教授 工学部土木工学科
比重, 吸水率, 粒形等の物理的な性状は冷却, 破砕過程 その他によって影響を受け, 製造所ごとに品質が異なる ほか, 生産時期によって品質に若干の差異を生ずること もある。従って使用に当っては良質の製品を選定するこ とが大切であるが, JIS 指定工場などのように十分管理 された工場から出荷される高炉スラグ砕石は, 一般の砕 石に十分比肩できる品質のものであるので, この指針で はJIS A 5011 に適合したものを用いるよう定めでいる。 JIS A 5011 では，高炉スラグ砕石を下表に示すよう な $\mathrm{A}$ 及び $\mathrm{B} の 2$ 種に分類している。この指針でもるれぞ れに対応した使用上の標準を示しているが，第一に使用 を推奨しているものは，Bに分類されるものであり，A のものは耐久性が重要視されず，かつまた設計基㔼強度 が $210 \mathrm{~kg} / \mathrm{cm}^{2}$ 末満のコンクリートに限定するようすす めている。

このように, 高炉スラグ砕石の分類によって使用の範 囲を違えた理由は, 高炉スラグ砕石コンクリート资実際 の構造物に使用された実績が限られており, 耐久性を判 断する資料に乏しいこと, 後述するように両者の行類の 間でコンクリートの品質にいくぶんの差異があるミと等 を考慮したためである。しかし，分類 $\mathrm{A} に$ 属するものでも これを用いて入念に施工をするのであれば，工事の目的 に合致した結果が得られる場合も少なくないと思れれる ので, 今後においてこの種の高炉スラグ砕石を使朋した 実績と研究調査の結果を積み重ねれば, さらに広䡉な使 用を検討する際の重要な基礎になるものと考えらねる。

高炉スラグ砕石の有害物含有量の限度ならびに品質規 定については，おおむね JIS A 5011 の規定と同じであ るが,特に洗い試験で失われるものについて最大值を 5.0 \%とすることとした。高炉スラグ砕石の微粉末は兂砕処 理の過程で混入する無機質の鉱物粉であるが，骨柿:粒の 表面に気孔が多いため微粉末が気孔に付着し，洗い試験 で失われるものの含有量がいくぶん大きくなる傾后があ る。実験の結果によればこの含有量が $7 \%$ 程度以下であ れば,コンクリートの諸性質に悪影響はなく，好結果を

高炉スラグ砕石の分類

\begin{tabular}{|c|c|c|c|}
\hline 分類 項目 & 絶乾比重 & 吸 水 率 & $\begin{array}{c}\text { 単位容積 } / \text { 重量 } \\
(\mathrm{kg} / l)\end{array}$ \\
\hline A & 2.2 以上 & 6 以下 & $1.25 \mathrm{E}$ 上 \\
\hline B & 2.4 以上 & 4 以下 & 1.35 E，上 \\
\hline
\end{tabular}


もたらすこともあることが認められている。このため高 炉スラグ砕石が安定した品質を確保することも配慮して このように定めたのである。なお,この指針では粘土塊， 軟らかい石片ならびに石炭, 亜炭等で比重 1.95 の液体 に浮くものについての規定はないが，これはこの種の物 質が製造過程で混入する恐れがないからである。

気象作用を受けるコンクリートに高炉スラグ研石を用 いる場合には，過去の経験，またはその骨材を用いたコ ンクリートの凍結融解試験の結果によって, その骨材の 耐久性を判断することとした。高炉スラグ砕石を用いて つくった $\mathrm{AE}$ コンクリートについての凍結融解試験の 結果によれば, 分類 Bを用いた場合の凍結融解に対する 抵抗性は普通骨材を用いた場合と同程度であり，また実 際の構造物コンクリートの調査結果でも良質なものは耐 久性の高いことが示されている。従って, 分類 $\mathrm{B}$ の高炉 スラグ砕石の耐久性は普通骨材の場合と実用上同等と考

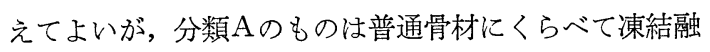
解試験の結果が若干劣る傾向にあるほか, 使用実績も明 らかでもないので, 耐久性が重要視されるコンクリート には用いてはならないこととしている。

3. 高炉スラグ砕石コンクリートの品質＼cjkstart高炉スラ グ砕石コンクリートの品質については, 土木学会無筋及 び鉄筋コンクリート標準示方書 (以下R C示方書とす) の規定とほぼ同じであるが，高炉スラブ砕石が河川砂利 に比べて角ばって㧍り，また表面組織が粗である粒が含 まれているので, コンクリートのワーカビリチーを向上 させるため， $\mathrm{AE}$ コンクリートとすることを規定した。

なお, 高炉スラグ砕石コンクリートの特性として, 絶 乾比重の值が 2.1 以下の高炉スラグ砕石を用いると, コ ンクリートの強度は小さくなる傾向にあるが，2.3 以上 のものでは一般に通常の砕石を用いた水セメント比が同 一のコンクリートと大差のない強度を示すこと, 吸水率 のかなり大きい高炉スラグ砕石を用いた場合は通常の砕 石を用いた場合にくらべて凍結融解に対する耐久性が劣 る傾向を示すこと等を解説で示した。

\section{4. 高炉スラグ䂶石の取扱い高炉スラグ砕石は,} 所要の含水量が均等に維持されるよう管理されなければ ならないことを規定した。すなわち，高炉スラグ䂶石は 通常の砂利, 砕石に比較して吸水率が大きく, また時間 の経過泮い, 吸水される水量が大きくなる傾向があ る。従って, 高炉スラグ砕石を乾燥状態で使用すれば, コンクリートの運搬中や打込中にコンシステンシーが変 化することも考えられるので，とくにポンプ圧送の場合 にはプレウェッチングのような吸水処置をある程度行う のが適当であることを解説で示した。

5. 配合 コンクリートの水セメント比を, 圧縮強 度, 耐久性あるいは水密性をもととして定める場合の規

Vol. 16, No. 10, Oct. 1978
定はR C 示方書の場合と同じである。ただし，耐久性を もととして定める場合については，分類 $\mathrm{B}$ の高炉スラグ 砕石を用いることを前提とした規定となっている。

6. 練りまぜおよび運搬高炉スラグ砕石コンクリ 一トの練りまぜ及び運搬については, 普通骨材の場合を 対象とした R C示方書の規定と同じである。しかし，吸 水率の大きい分類 $\mathrm{A} の$ 高炉スラグ硒石を気乾状態で用い る場合には，高炉スラグ砕石がミキ步内で吸水現象を起 し, コンクリートのコンシステンシー, 強度等が変動す るおそれがあるほか，コンクリートポンプで圧送すると 圧送後のスランプ低下が大きくなり，極端な場合には閉 そくが起り易くなることが指摘されている。そこで，こ のような場合には十分注意して取扱うことが必要なこと を解説で述べている。

7. 打込みおよひ養生 高炉スラグ 砕石 コンクリー 卜の打込み，締固めおよび養生は，一般には普通骨材を 用いる場合と同様に考えて行えばよいことを示した。

\section{8. 設計計算における一般事項}

（1） 単位重量：設計計算に用いる高炉スラグ砕石コ ンクリートの単位重量は試験して求めるべきものである が, 特に試験を行わない場合には $2.3 \mathrm{t} / \mathrm{m}^{3}$ としてよい こととした。

（2）弹性係数：不静定力または弾性変形の計算に用 いる值として, 設計基準強度が $400 \mathrm{~kg} / \mathrm{cm}^{2}$ の場合を削 除したほかは，RC示方書の規定と同じとした。

（3）コンクリートの乾燥収縮, クリープ及び熱膨張 係数：これらに関する規定はR C示方書に示されている 普通骨材コンクリートの值と同じとした。

(4) 許容応力度 : 許容せん断応力度及び許容付着応 力度の值として, 設計基準強度が $400 \mathrm{~kg} / \mathrm{cm}^{2}$ の場合を 除いたほかは，R C 示方書の規定と同等の值とした。

（5）一般構造細目：高炉スラグ砕石を用いる鉄筋コ ンクリート構造物における一般構造細目は，一般にR C 示方書によってよいこととした。なお, 高炉スラグ砕石 を用いる場合, 鉄筋のかぶりを普通骨材を用いる場合と 同等にしてよいかどうかが懸念される。このため, 高炉 スラグ砕石コンクリートの水密性及び中性化についての 試験結果を検討し,さらに建設後 $30 \sim 50$ 年を経過した コンクリート構造物の中性化深さ及び鉄筋の発錆状況に ついても調查したが，入念に施工すれば，これらを普通 骨材コンクリートの場合と同等にすることができること が示された。そこで, 分類 $\mathrm{B}$ の高炉スラグ砕石を用いる 鉄筋コンクリート構造物では, 一般の場合鉄筋のかぶり を普通骨材を用いる場合と同等にしてよいこととした。

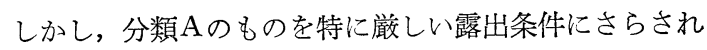
る構造物に用いる場合には, 鉄筋のかぶりはいくぶん大 き目にするようすすめている。 